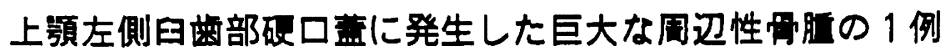

中出修・吉川泰子・八百樫和秀・大内知之

阿部英二・管野秀俊・贺来亨・奥山富三

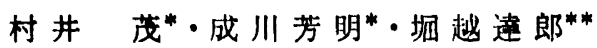

\section{A case of large peripheral osteoma occurred in the hard palate of the left maxillary molar region}

\author{
Osamu Nakade - Yasuko Krchikawa - Kazuhide YaEgashi • Tomoyuki Ohuchi \\ Hideji Abe - Hidetoshi Kanno - Tohru Kaku - Tomizo Okuyama \\ Shigeru MUrai* - Yoshiaki NarikawA* - Tatsuro Horikoshi**
}

\begin{abstract}
A 41-year-old woman was referred by her dentist because of a tumor mass in the left maxilla which interfered with swallowing and speech. She first noticed a small and painless mass about 20 years ago.

Macroscopic examination showed a pedunculated tumor mass, the size of hen's egg, attached to the hard palate of the left maxillary molar region.

The radiographic examination revealed a densely radiopaque rim surrouding a central region showing a slightly ground glass-like pattern.

Histologically, the specimen consisted of a rim of compact bone enclosing a central area of cancellous bone. The marrow spaces contained the fatty or fibrous tissue.

The diagnosis was cancellous osteoma.
\end{abstract}

Key words: benign bone tumor, peripheral osteoma, cancellous osteoma

腥言

骨腫は成熟骨の增殖を特徵とする良性腫瘍で, 顔面頭 蓋骨はその好発部位とされている。

東日本学图大学齿学部口腔病理学教室

（主任：奥山富三教授）

*西館市立病院䅈科

（主任：村井 茂）

**元東日本学園大学歯学部口腔外科学教室

（現主任：金沢正昭教授）

Department of Oral Pathology, School of Dentistry, Higashi Nippon Gakuen University. (Chief: Prof. Tomizo Okuyama)

* Department of Dentistry, Hakodate Municipal Hospital (Chief: Dr. Shigeru Murai)

** Department of Oral and Maxill of acial Surgery, Higashi Nippon Gakuen University (Chief: Prof. Masaaki Kanazawa) 受付日：昭和62年 1 月 9 日
今回われわれは上䅡左側曰歯部硬口蓋に有茥性に発育 した駡卵大の周辺性骨腫の 1 例を経験したので報告す る.

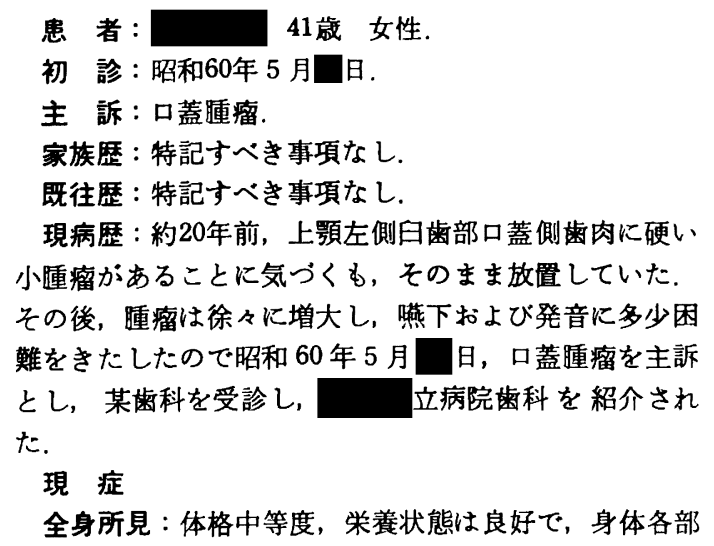

全身所見：体格中等度，栄養状態は良好で，身体各部 


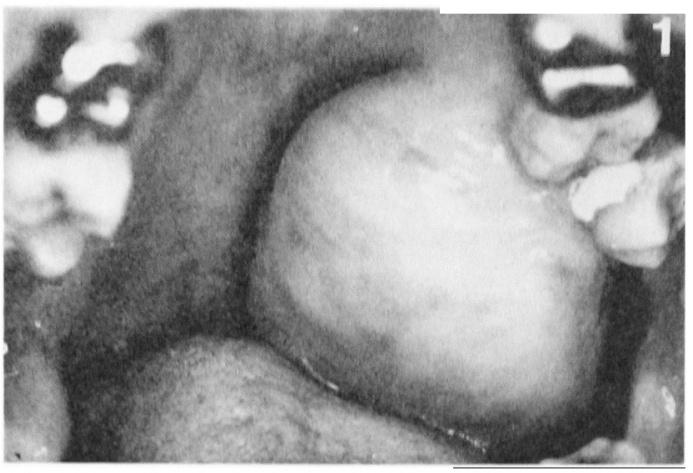

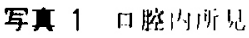

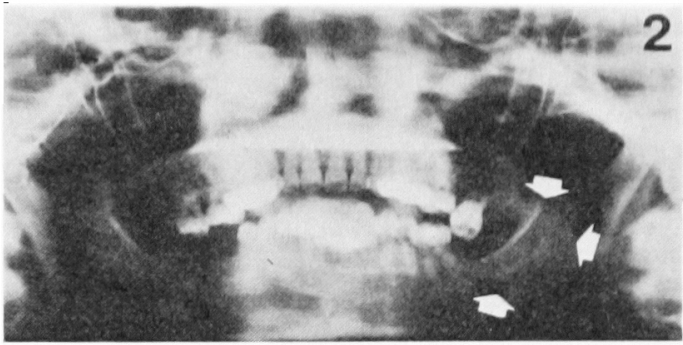

写直 2 ハントモX線所見

矢印は上影左㑡曰菌部の睡留を示な。

の骨格，その他異常所見は唢められなかった。

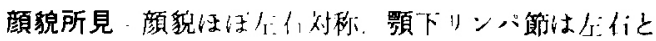

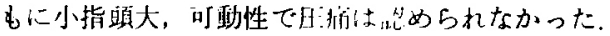

口腔内所見： 15〜8 部の口蓋侧から上類結節にかけ， 約 $5 \times 3 \mathrm{~cm}$ の限局性で，口腔内に有茥性に発育した骨

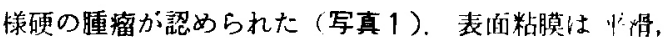
多少荅白で，びらん，浊拈は認められなかった。睡瘤に 接した17は煩側に転位，挺出していたが，|56にこの ような転位，挺圠は認められなかった。開口障害は認め られなかったが，ごく軽度の藇下扰よび楎暗障害が認め られた。

血液・生化学検査、異常所見なし。

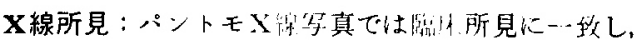

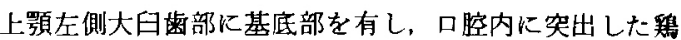
即大の境界明瞭な不透過像が認められた（写真 2)。卜 モグラフィーX积写真でるほぼ同様の所見が浔められた (写真了).

CT 所見：左側硬口蓋から軟口蓋にかけて，辺縁は骨 様の石灰化像を示し，内部は low-density の構造をるつ 腫瘤が認められた（写真 4).

臨床診断：上顎骨周辺性骨睡.

処置および経過：昭和60年 8 月⿴日，GOF 全身麻醉 下に 67 抜去啳，エアサーシィトーム拈よ゙骨ノミにて 腫瘤基底部より切断摘除した。腔内と上觀洞が交通し

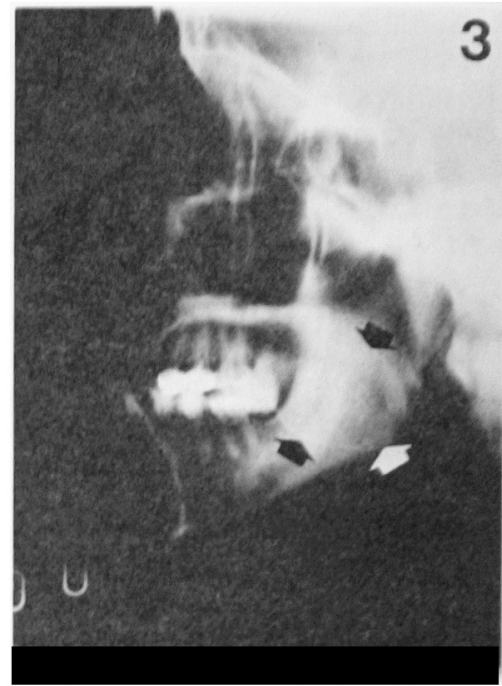

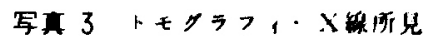

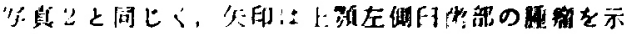
$+$

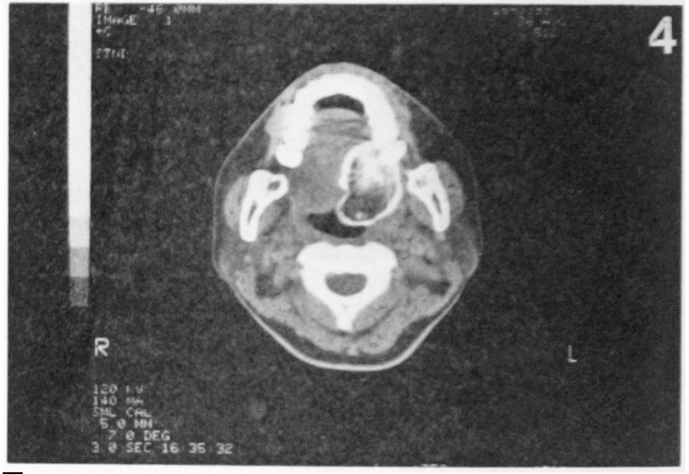

写真 4 CT 所胃

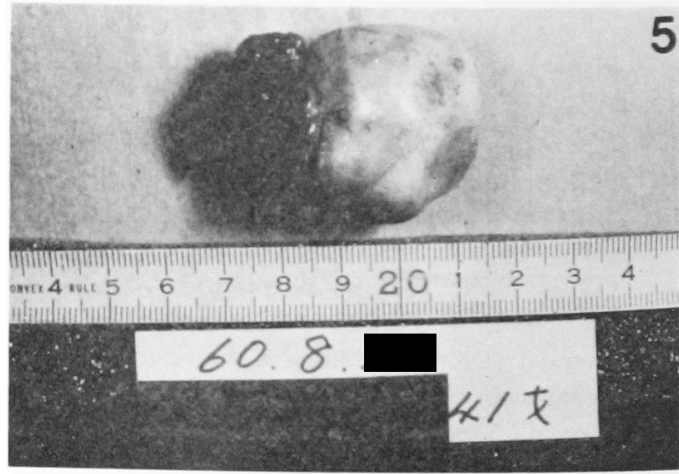

写真 5 摘出物所見 


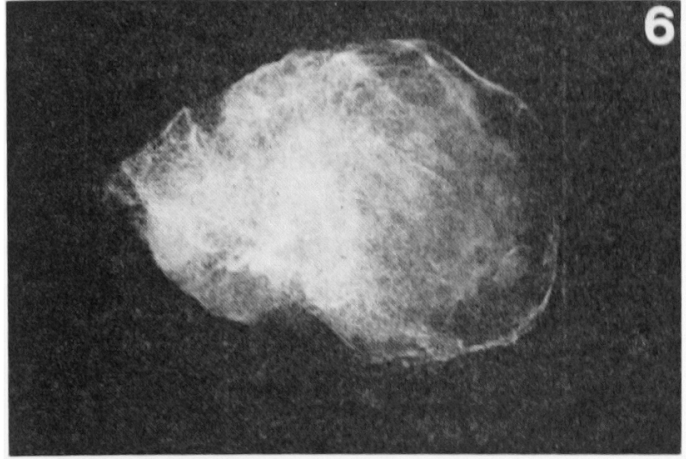

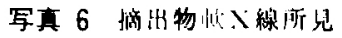

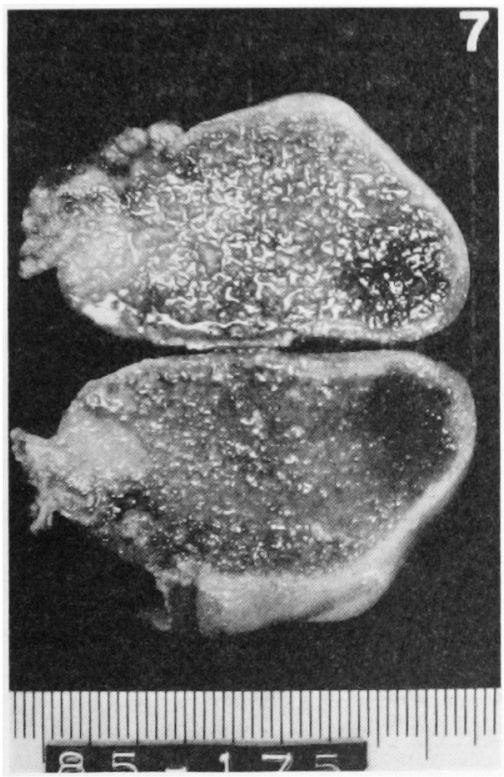

写真 7 摘出物割面所見 海綿骨様の構造を示している。

たため，手術部にアクロマインン軟高を塗布したガーゼ を垻塞した，術後経過良好で，1か月後に上影洞交通部 に栓寨子のついた局部床義歯を装着した，術後約 1 年の 現在、再発は認められず，器下および權音障書も改善し た.

摘出物所見：摘出腫瘤は大きさ的 $5 \times 3 \times 3 \mathrm{~cm}$ であり (写真 5)，その軟X線写真では表面は一層の強い不透洫 帯が認められ，内部はスリガラス㫪の不透過俊を呈して いた（写真 6)。摘出物割面は黄白色を星し，海綿骨様 の構造を示していた（写真 7).

病理組穖学的所見：尰瘤最表層は緻密な骨質よりなる 層で被われ，その内部は比較的細い骨架が無数かつ不規 則に形成されており，骨梁間には脂肪組織あるいは眯性

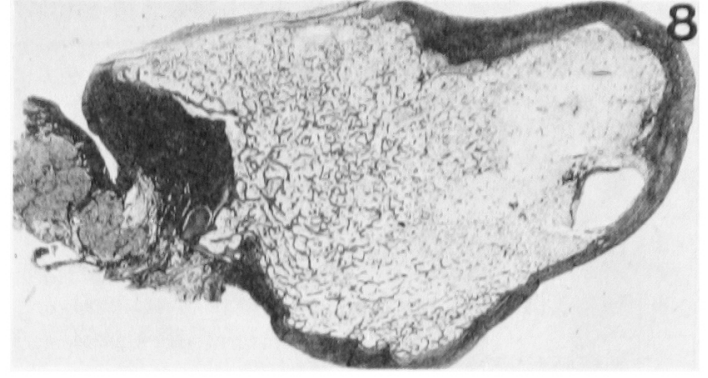

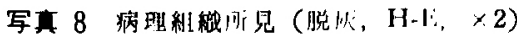

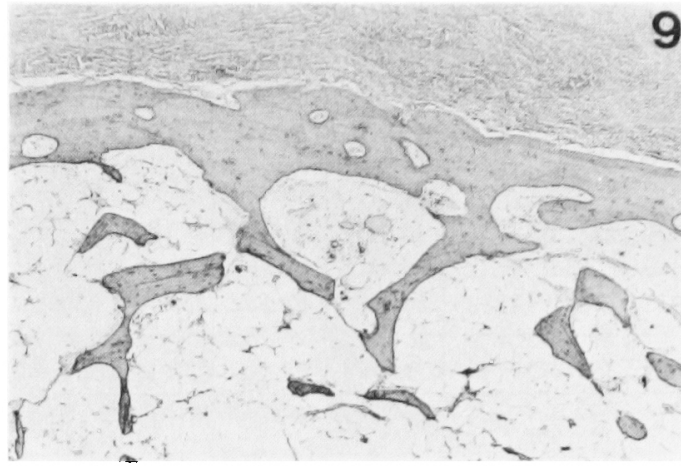

写直 9 病理粗織所見（脱灰， H-E， $\times 45 ，$ 写真 8 の-..部抾大)

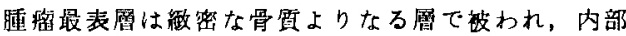
は細い骨梁が繁数かっ下規則に非成されて㕲り，骨

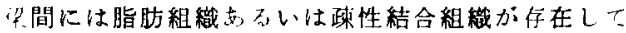
いる。

稓合組織が存在していた（写直 8，9）。 病理組織診断：海綿状骨腫.

考察

骨腄は内骨膜あるいは外骨膜より発生し, 成熟骨の增 殖を特徵とする良性腫場で，その発生部位から，内骨瞙 性に䫑骨の内部に発生する中心性骨腫と外骨膜性に顎骨 の表面に発生する周辺性骨腫および軟組織に発生する傍 骨性骨腫に分けら九る。また病理組織学的には稉密な層 板骨質の增殖から成る維密骨腫と骨質が比較的少なく海 綿質様の棈造をもつ海綿状骨腫に分けられる 例は上顎左側臼雪部硬口蓋に発生した周辺性骨腫で，有 茎性に発育し，大きさ約 $5 \times 3 \times 3 \mathrm{~cm}$ と巨大であった。 また，病理組織学的には海綿状骨腫であった。

われわれが文献を涉椫した範囲では，本邦に执いて報 告された上䫑骨骨畽は表1のようであり，少数例ではあ るが自験例を含めて検討を加えだ〜15)

大きさでは14例中，明らかなるのは11例でそのうち最 


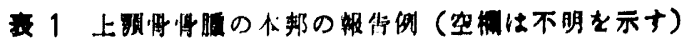

\begin{tabular}{|c|c|c|c|c|c|c|c|c|c|}
\hline & 踙 台 者 & 胙岨命 & 性: & 比間 & $大 き(\mathrm{~cm})$ & 部位 & 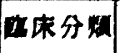 & & その他 \\
\hline 1 & 後 (1951) & 19 & 우 & 的 3 年 & (烣卵大) & 白暗激烟侧 & 用边性 & 酯数状 & \\
\hline 2 & 後 暴(1951) & 42 & 우 & 約10年： & （胡桃大） & 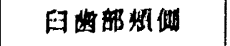 & 椆欢性 & 背的 & \\
\hline 3 & 加革ら (1959) & 17 & 우 & & & 曰部蝴湖 & 用㲽性 & 踝 & \\
\hline 4 & 加湿ら (1959) & 42 & 우 & 的 3 年 & & 曰部规湖 & 䎟双性 & 16 & \\
\hline 5 & 加滕 ら (1959) & 10 & 우 & 䄪 1 年 & & 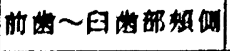 & 閏边性 & & \\
\hline 6 & 河村 5 (1962) & 21 & 우 & 䄪 6 年 & $5 \times 3 \times 1.5$ & 配口青 & 凋双性 & 泚㳯状 & \\
\hline 7 & 中村 ら (1970) & & & & （小畉人） & 上㛚湖 & & & \\
\hline 8 & 饴瀬ら (1975) & 18 & 우 & 数年 & 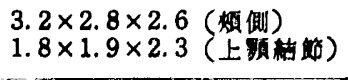 & 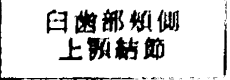 & 物观性 & 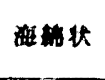 & $\dddot{x}$ \\
\hline 9 & 小山ら (1982) & 39 & 우 & & （搬指㖽大） & 大眐品 & 中心姓 & & \\
\hline 10 & 竹 松(1982) & 48 & $\hat{\delta}$ & 15～16年 & $\begin{array}{l}1.0 \times 2.0 \times 2.5 \\
1.0 \times 1.5 \times 0.5\end{array}$ & 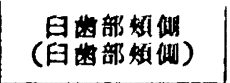 & 周訊住 & 政 & * \\
\hline 11 & 本間ら (1982) & 56 & 今 & 䄪 2 年 & $2 \times 2 \times 2.5$ & 上页湖 & & 海思状 & \\
\hline 12 & 牧角ら(1982) & 6 & ๙ & & $2.2 \times 1.8$ & 硬口益 & 夙扨性 & 密 & \\
\hline 13 & 正木ら(1983) & 33 & 우 & & （指顕大） & 上汿洞 & 伤骨性 & 海盟状 & \\
\hline 14 & 自䀫例 (1986) & 41 & 우 & 䄪 20 年 & $5 \times 3 \times 3$ & 硕口晸 & 周边性 & 海能状 & \\
\hline
\end{tabular}

（同一口察内 2 调）

小のものは $1.0 \times 1.5 \times 0.5 \mathrm{~cm}^{12)}$ で，取大のものは約 $5 \times$ $3 \times 3 \mathrm{~cm}$ (自験例) で，自験例は上頻骨得腫としては， かなり大きいものの籍暷に属するものと思われた（表 1 ).

部位別ではこれら14例中16個の腫瘤が認められ，日齿

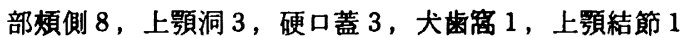

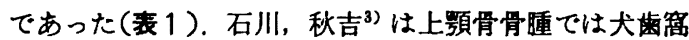
部，硬口蓋，洞部に多いと報告しているが，これら14例 について見れば，田歯部煩側が最も多く，次に上顥洞，

硬口蓋が多く，犬歯窩には少ない結果となった。

症状を自覚してから来院までの期間については明らか なすのは 9 例で，最短のものは約 1 年?)，取長のものは 約20年 (自験例), 平均䄪 7 年であった（丧1).

臨床的分類では明らかなるの12例中，周辺性骨腫 10 例，中心性骨畽 1 例，傍骨性骨腫 1 例であった(表 1 ). 一般に文献的には周辺性骨腫が中心性骨隀より多いとい われ，傍骨性骨腫はまれたといわれているる,8).

病理組織学的分類では明らかなるの11例中緻密骨腫 5 例，海綿状骨腫 6 例で，ほぼ同数であった.

性別では明らかなるの13例のうち，女性が10例，男性 が3 例で，女性に多い傾向にあった（表1）．従来報告

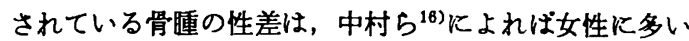

といわれ，河村らきはその差は明らかでないと述べてい ろ.

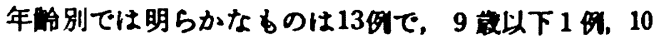

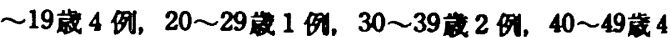
例，50藏以上 1 例で，あらゆる年代に及んでいた（表 1). 好発年㫻について，Gorlin and Goldman"1はらら

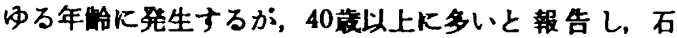
川, 秋吉”) はおるに10～35藏代の人に多いと，また河村 ら ${ }^{8)}$ は20〜40藏に多いかi，その発生年跲は，骨発育の旺 盛な思春期に多いだろらと推测している。

本邦における巨大な有茥性骨重には，自非例の他に上

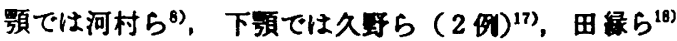
の報告があるが，いずれる海綿状骨湩であり，巨大な有 茥性骨腫には海綿状骨腫が多いことが示暖された。

骨畽の定娄に阅して現在までさまざまな討詥がなされ

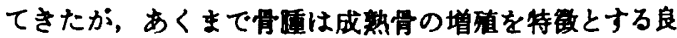
性腫瘁であり，外来刺激あるいは㷋症による反応性骨過 形成や炎症組耤の化生によって生じた病的骨形成あるい

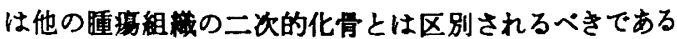
が, 多くの著者は顥骨の骨瘇においては必ずしもその爁 別は容易でないと述べていろ. Shafer は䫑骨は感染に さらされる機会が多いので，刺敏あるいは炎症によって 
形成される骨瘤と真の胛煌性のものとの監别は常に可能 とは限らないといっている，石川，秋吉”は䏸の病理 組織学的所見について，增殖した骨組械の橉造は正常の 骨組機に近いるのから不完全なるのまでいろいろである と述へ，真の骨脯か否かを病理組糡学的所見に上っての み判断するのは必ずしも可能でないことを示昗してい る. Gorlin and Goldman") (骨隀とい5記就が独立し た病変として使われているか閶問たとし，完全に举化し た骨軟骨腫，外传による外骨症，炎症組樴の骨化したも の，線䊒性骨異形成症の高度に骨化したものなどにおい ても骨挝として用いられてきたとしている。

自験例成しては患者が自觉してから来院するまでの 期間が約 20 年と経過が長く，その間徐々に增大し，大き さが約 $5 \times 3 \times 3 \mathrm{~cm}$ と巨大であったこと，病理組織学 的にも资症あるいは軟骨組噺が認められなかったこと，

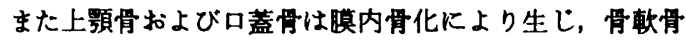
腫の発生部位としてはきわめてまれな部位であることか ら，骨腫と診断すべきであろらと思われる。

しかし、ごくまれに上頻においても骨軟骨畽の報告20) があること，また軟骨内骨化においても海綿骨を生ずる ので，完全に骨化した骨軟骨腫の可能性も否定はできな い.

自験例の脂肪䯣様の組織発生についても興味深いとこ ろである. Thoma ${ }^{18)}$ の海綿状骨畽の 1 症例では，大部 分は脂肪跹粎で，ごく一部に赤色骾を有するすのがある が，自験例においては赤色䯣を有していないので，発生 初期に造血能を有していたか否かは明らかでない．

骨睡の処置は比較的簡単な術式で摘除され，再発はま れとされている. 自験例においても術後約 1 年 4 か月の 現在, 再発は認められていないか，骨腫は発育が緩慢で あるから，長期間の経過钼察が必要と思われる。

\section{結語}

41歳，女性の上頼左側曰歯部硬口蓋に発生した巨大な 周辺性骨畽の 1 例を経験したので，その概要を報告する とともに若干の文献的考察を行った。

な招，本論文の要旨は，第 40 回日本口腔科学会 総会 （昭和61年 5 月）において発表した。

\section{引用文 塥}

1) Kragh, L.V.: Bone tumors of the jaws. In Gorlin, R.J., H.M. (ed): THOMA'S Oral Pathology. 6th Ed, vol. 1. Mosby, St. Louis, 1970, p 560-562.

2) Huvos, A.G.: BONE TUMORS. Diagnosis, Treatment and Prognosis. 1th Ed. W.B. Saunders. Philadelphia, 1979, p 1-6.

3）石川梧朗，秋吉正典：口腔病理学 II. 改行版，水 末售店，京都，1982，p 553-557。

4) Shafer, W.G. and Hine, M.K.: A Textbook of Oral Pathology. 4th Ed. W.B. Saunders, Philadelphia, 1983, p 163-164.

5) Lucas, R.B.: Pathology of Tumors of the Oral Tissues. 4th Ed. Churchill Livingstone, 1984, p 191-195.

6）後藤吉男：上頻に発生した骨腫の 2 例。找茶の水 学会誌 3: 93-96 1951.

7) 加藤邦義, 北村久弥: 骨腫の 3 例. 口外誌 5 : 322-325 1959.

8）河村正昭，赤坂麻子，他：口蓝の有董性骨㞌 の 1 例. 口外誌, 8: 153-155 1962.

9）中村平藏，新国俊彦，他：頼顔面湎城に生した骨 腫の 4 例について。科誌 17: 346-347 1968.

10）去瀬洋二, 服部千秋, 他 : 上䫑に発生した周匄性 骨腫の 1 例. 日口外誌 21: 221-224 1975.

11）小山茂樹, 長香駿一郎, 他：中心性骨腫の 1 例. 日口外誌 28: 21391982.

12）竹松啓一：在上額骨飞発生した周辺性骨原の 1 例. 交通医学, 36: 287-289 1982.

13）本間義章, 岡野冒治，他：上䫑洞内骨瘇の 1 例. 日外誌 28: 21471982.

14）牧角淳朗, 大田逸雄, 他：口蓋に発生した骨腫の 1 例. 日外誌 28: 13741982.

15）正木日立，矢島安朝，他：上影洞に発生した骨腫 の 1 例. 日口外誌 29: 18571983.

16）中村保夫, 渡辺文磨, 他：下顎舌側に発生した骨 畽の 1 例。 日只外誌 14: 134-136 1968.

17）久野吉男，古屋英媇。他：下影骨舌㑡飞発生した 大きな骨腫の 2 症例について。 日外誌 17：48511971.

18）田緑 昭, 上田 忠, 他：下䫑舌㑡に発生した骨 腫の 1 例。 日只外誌 21: 62-65 1975.

19) Thoma, K.T.: Oral Surgery. 5th Ed, vol. 2 Mosby, St Louis, 1969, p 969-972.

20) Brady, F.A., Sapp, J.P., et al.. Extracondylar osteochondromas of the jaws. Oral Surg, 46: 6581978. 